\title{
A fond and grateful farewell
}

\begin{abstract}
After 16 years of discovery, excitement, and getting to know some of the best scientific and medical hearts and minds in this country (in many cases, the world), I am leaving Izindaba to take up a freelance career in the healthcare field.

Journalism tends not to favour the salaried soul, and a graceful confluence of events has given me the impetus I need to propel me outwards and hopefully upwards. It's been a huge privilege being privy to some of the quiet machinations of major medicopolitical players, scientific advances, AIDS denialism/ heroism, dysfunction, and triumphs against all odds by inspirational men and women. It's the ones who refuse to accept impossibility who will linger longest in my affections their shared attributes being a big heart, compassion for their fellow man, singleminded determination and a vision of 'how it could be'.
\end{abstract}

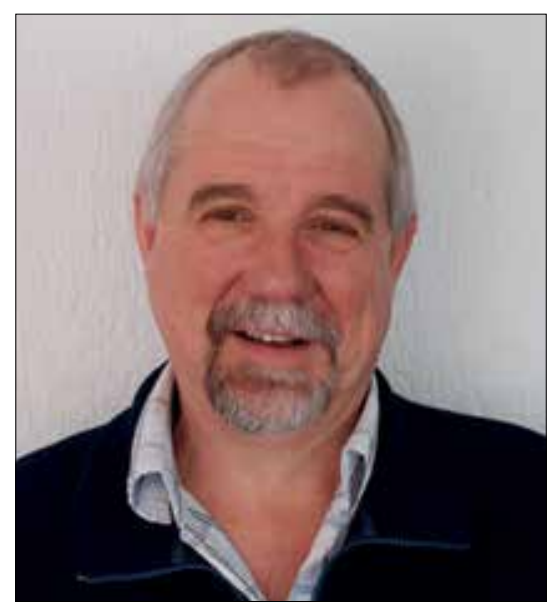

I must have brought something to the party, or I guess not so many of my sources would have confided in me - or trusted me to represent their views in a way that puts readers first, respects individual context and confronts issues. One of the greatest gifts of journalism is the perspective you get in chatting to so many different people about a single issue. I'm glad I could bring six journalism awards, mainly for commentary and analysis, to the $S A M J$ over the years, but I am also very aware that the journal title opened doors. I had three amazing mentors, all with great integrity, knowledge and experience, to support and guide me: Profs Dan Ncayiyana, JP van Niekerk and Janet Seggie. If I have any advice for my successor, it will be never to break a trust, to check back for accuracy (only), and to stand firm on solid ground.

\section{Chris Bateman}

chrisb@hmpg.co.za

S Afr Med J 2016;106(11):1066

DOI:10.7196/SAMJ.2016.v106i11.11475 